Production and Marketing Report

\section{Soil Management in Irrigated Pecan Orchards in the Southwestern United States}

\author{
S. Miyamoto ${ }^{1}$ and \\ J. Benton Storey ${ }^{2}$
}

Additional index words. chiseling, subsoiling, soil amendment, sodding

Summary. Irrigated pecans in the southwestern United States have been planted in every soil imaginable, and tree performance has become highly soildependent. Desperate attempts to deal with this poor soil selection has led to advancements in soil management, consisting primarily of physical measures, such as chiseling and trenching. Chemical amendments appear to have played a secondary or supplemental role. Meanwhile, soil structural degradation, mainly compaction and aggregate destruction, began to cause poor water penetration, die-back of deep roots, and resultant loss of tree vigor. These problems have been dealt with primarily by chiseling. In the future, spiking and sodded-floor management are likely to become increasingly important. Scientific examination of soil management practices has lagged, but has provided some rationale and targets for soil management. $\mathrm{H}$ should play an increasingly important role in refining

'Professoc Texas A\&M University Agricultural Research and Extension Center 1380 A\&M Circle, El Paso, TX 79927.

${ }^{2}$ Professor, Department of Horticultural Sciences, Texas A\&M University College Station, TX 77843.

This research was conducted at the Texas A\&M Univ. Agricultural Research and Extension Center at El Paso. Use of trade names does not imply endorsement of the products named nor criticism of similar ones not named. The cost of publishing this paper was defrayed in part by the payment of page charges. Under postal regulations, this paper therefore must be hereby marked advertisement solely to indicate this fact. these measures and in establishing a comprehensive soil management program in which the soil is viewed as a plant growth medium and an integral component of cost-effective orchard management.

rrigated pecans in the southwestern United States have been planted in a wide variety of soils, ranging from sand to clay, shallow to deep, and soft to very hard. Needless to say, tree performance has become highly soil-dependent (Miyamoto and Helmers, 1988). This strong dependency on soils is undoubtedly related to the nature of pecan trees, which are susceptible to water and salt stress, waterlogging, poor aeration, and soil hardness (e.g., Alben, 1958; Loustalot, 1945; Miyamoto and Gobran, 1983; Miyamoto et al., 1985, 1986a, 1986b; Rieger and Daniel, 1988; Smith and Ager, 1988; Smith and Bourne, 1989; Sparks, 1989). The pronounced effect of soil on tree growth also is attributed to cumulative effects; e.g., a small difference in annual growth rate is magnified over a long lifetime of a pecan tree.

Many of the advancements in soil improvement and management in the past decades have resulted from desperate attempts of growers to deal with their unfortunate soil selection. The development of necessary techniques, however, had been hampered in part by the prevailing notion that tree roots should not be damaged or disturbed. This idea prevented the introduction of physical means of managing soils; such as trenching and chiseling; until the 1980s. However, root pruning caused by chiseling or trenching was not as harmful as originally feared and was even beneficial in correcting an undesirable pattern of shallow root development.

Recently, soil compaction caused by an everincreasing use of heavy equipment has led to shallower penetration of water, die-back of deep roots, and resultant loss of tree vigor. Another trend is that many growers have been converting from clean cultivation to sodded-floor management to reduce production costs. This new trend can lead to environmentally friendly orchard management without increasing production costs. The purpose of this paper is to outline the progress made in managing old problems of poor soil selection, current problems of soil structural degradation, and future needs for developing environmentally friendly soil and orchard-floor management.

\section{Improving poor soils}

Pecan trees perform best in deep, welldrained sandy soils, including loamy sand, sandy loam, and silt loam (Miyamoto and Helmers, 1988). As the soil deviates from this ideal texture and profile, tree performance usually declines. Soils that frequently have caused problems include 1) shallow upland soils with a calcic horizon (commonly referred to as a caliche); 2) clay soils with inadequate permeability; 3) soils that are affected by salts, especially sodium; and 4) soils affected by fluctuating high water tables.

There has been good progress in dealing with shallow upland soils with a calcic horizon. The principal problem with this type of soil is physical impedance to vertical root development The calcic horizon, even if softened by irrigation, usually prevents root penetration, causing roots to develop into a shallow lateral pattern. This makes trees highly susceptible to water and nutrient stress. Many growers have corrected this problem successfully by chiseling to 60 to $90 \mathrm{~cm}$ deep using heavyduty equipment. Deep chiseling is performed usually on one side of the tree rows in the first year and on the other side several years later to minimize the shock to the trees. This type of operation should be implemented during the dormant period to destroy the caliche layer and reestablish the root systems to a greater depth, preferably during the early stage of tree development.

Managing clay soils with inadequate permeability remains a difficult task, especially when irrigation water contains high levels of salts. Experience in El Paso Valley, Texas, shows that economic yields are difficult to obtain from trees planted in clay, and even in silty clay loam, when salinity of irrigation water reaches 1 to $1.5 \mathrm{dS} \cdot \mathrm{m}^{-1}$ (Miyamoto and Gobran, 1983) High salinity is certainly not the sole reason for poor tree performance in clay soils. Waterlogging and oxygen deficiency often associated with surface irrigation cause difficulties in water uptake and photosynthesis, and may even cause defoliation (e.g., Alben, 1958; Loustalot, 1945; Smith and Ager, 1988; Smith and Bourne, 1989). Transplanting to better soils is certainly a consideration. When sandy soil or sand is present below the clay layer, however, it is possible to bring the sandy soil to the surface with a backhoe or a large trencher. Some success was reported when trenching or pitting was implemented to disturb the profile near the trees (Miyamoto and Gobran, 1983). The purpose of this type of treatment is to improve water intake and internal drainage in the zone of maximum root activity. The subsoil, however, should not be affected by high water tables that limit root extension. Otherwise, the effect of trenching is shortlived, as roots fill up the trench above the water table. Placing a trench at the midpoint between tree rows can help surface drainage, but tree responses are usually slow, since improvements in soil conditions are confined to the area where the root density is the lowest (Miyamoto and Gobran, 1983). When irrigation water is low in salts $(<500 \mathrm{ppm})$, clay soils, especially those that develop extensive cracks, have been managed rather successfully with the use of light and frequent irrigations, including sprinkler irrigation.

The occurrence of salt-affected soils in irrigated pecan orchards is common in upland soils 
irrigated with moderately saline water (1 to 2 $\left.d S \cdot m^{-1}\right)$, and in alluvial soils with poor drainage or inadequate permeability. Tree performance is reduced when salinity of the soil saturation extract reaches 2 to $3 \mathrm{dS} \cdot \mathrm{m}^{-1}$; tree mortality may occur at 6 to $8 \mathrm{dS} \cdot \mathrm{m}^{-1}$ in the saturation extract (Fig, 1). In sandy upland soils irrigated with moderately saline water, tree performance may be reduced at lower soil salinity measured in the saturated extract, as the actual salinity of soil solutions tends to be higher in sandy soils than in clay soils at a comparable saturation-extract salinity.

Managing salt-affected soils is highly sitespecific. Salt-affected sandy soils with deep water tables have been managed successfully with leaching irrigation in the spring (Miyamoto, 1989), In finer-textured soils (e.g., clay loam, silty clay loam), salinity control is usually achieved during the dormant period using chiseling, followed by two or three consecutive leaching irrigations up to several weeks (Miyamoto, 1989), In silty clay or clay, it is usually difficult to achieve adequate salt leaching unless some type of soil-profile modification is used before leaching irrigation.

Some orchard soils in the southwestern region are affected by sodium, most frequently as a result of irrigation with water high in sodium or as a result of poor drainage during soil formation. Water application of various chemicals has been attempted, but usually with unconvincing results. This is in sharp contrast to the success reported in California with chemical water treatments (e.g., Wildman et al., 1988). Irrigation water in pecanproducing areas of the southwestern region is considerably more saline and less sodic, making water-run application of chemicals less effective (Miyamoto, 1989; Miyamoto and Stroehleim, 1986), In addition, the effect of sodicity on reducing water intake rates is minimal in soils with minimal tillage compared to soils that undergo extensive pulverization through disking (Miyamoto and Enriquez, 1989; Pandey, 1985). Moderately sodium-affected orchard soils (exchangeable sodium $5 \%$ to $15 \%$ ) are reclaimed usually by chiseling followed by a surface-broadcast application of either sulfuric acid or gypsum before leaching if necessary. Helmers and Miyamoto(1990) reported successful leaching of salts in moderately sodium-affected soils by chiseling alone, but not necessarily by gypsum application (Table 1), It may take several seasons for gypsum to dissolve when applied at 15 t/ha or more. Chiseling breaks up compaction or dense soil structure, and a broadcast application of soil amendments prevents or minimizes soil structural deterioration caused by sodium at the soil surface (Miyamoto and Enriquez, 1989),

Some reports (eg., Acharya and Abrol, 1976) indicate that topdressing sodium-affected soils with a layer of sand $(<3 \mathrm{~cm})$ improved water infiltration, as the sand layer reduced dispersion of sodium-affected clays. This measure also may help to improve water infiltration in ordinary clay soil if used after deep chiseling. The sand falling into the chiseling cracks can act as water-conductive media, provided that the sand is not incorporated into the clay by disking. This means that sodded-floor management or chemical weed control may have to be used after sand dressing, However, quantitative evaluation of these potentials is yet to be performed for the soils of the southwestern region,

Soils affected by high water tables are common in irrigated orchards established along river basins, A high water table per se usually is not a serious problem as long as the table is stable and the water is low in salts, since pecan trees develop shallow lateral root systems (Miyamoto, 1989; Miyamoto and Helmers, 1988), There are many productive orchards with a root-zone depth of 45 $\mathrm{cm}$ over a stationary water table as shallow as 1.5 $\mathrm{m}$. The main problem occurs when the water table fluctuates. Root systems adjusted to a deep water table cannot function when the table rises, and trees experience difficulties with water uptake and associated physiological disorders, In addition, feeder roots are often subjected to high levels of salts, as the salts present in the lower root zone or a ditch bank are brought to the surface (Miyamoto, 1989). Table 2 shows such an example, which has occurred in several orchards along the Rio Grande when the river water level rose, Tree mortality after the rise of water tables was associated primarily with high salinity, rather than excess water,

Remedies to high water-table problems are highly site-specific, and poor results are associated often with poor selection of drainage measures. Three types of situations are usually encountered in pecan-producing areas of the southwestern region, The first type is the presence of

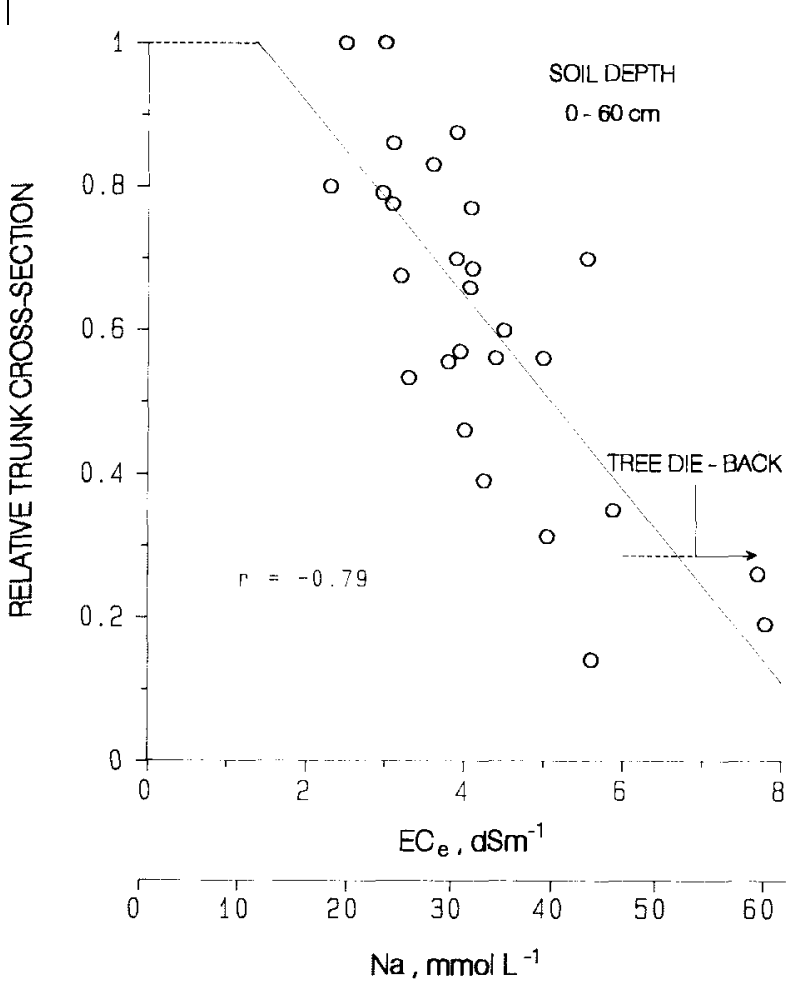

clay subsoil under sandy soils, which causes a perched water table, This problem is controlled usually by deep trenching to breakthrough the clay subsoil. The second type usually occurs in old depressions or laguna, where drainage was poor 10 begin with, that were filled during irrigation projects, Subsurface tile drains or open drains are usually used to correct this type of problem. Open drains should not be used in sand or silt because extensive cave-in can result, The third type usually occurs as a result of canal seepage or, at times excessive flow in the adjacent rivers or creeks. Canal lining or interception drains (either subsurface or open, depending primarily on soil texture) are used commonly to deal with this type of problem (Miyamoto, 1989), Once the water table begins to recede, and if high salt levels are present in the soil, salt leaching should commence in alternate rows to minimize drainage load. Flooding the entire orchard often results in the resurgence of the water table, making salt leaching difficult (Miyamoto, 1989).

\section{Managing soil structural degradation}

The loss of tree vigor in mature orchards was reported first in well-drained sandy loam and silt loam soils in northern Mexico, It was thought to be a case of overcrowding, the initial symptom of root-rot infection, or damage caused by nematodes, However, the problem was a case of reduced water penetration and associated die-back of deep root systems, In well-drained, deep sandy loam or silt loam, the root systems of pecans penetrate to great depths, Soil compaction or formation of a disk pan slows water intake and reduces water penetration depths, which leads to drying out of the deep roots and loss of tree vigor, This problem seems to have been compounded by the fact that many growers have failed to adjust irrigation scheduling for increased tree size (Miyamoto, 1985). Typically, growers tend to overirrigate young trees and underirrigate mature trees, especially in pump-irrigated areas where water supply rates are more or less fixed, Shallow chiseling (lo break up the compacted layer or disk pan) and increased irrigation usually correct this type of problem.

A problem similar to the

Fig. 1. The relationship between relative trunk cross-section and salinity and sodium concentrations in the saturation extract of soil samples colllected from 0 to $60 \mathrm{~cm}$ deep in an orchard in El Paso Valley Texas (Miyamoto and Gobran, 1983). 
Table 1. Effects of soil chiseling to a depth of $60 \mathrm{~cm}$ and surface-applied gypsum to Glendale silty clay at a 13 tha on soil salinity and sodicity by the end of one growing season; fieldtest in El Paso Valley, Texas.

\begin{tabular}{|c|c|c|c|c|}
\hline \multirow[b]{2}{*}{$\begin{array}{l}\text { Treatment } \\
\text { (depth or rate) }\end{array}$} & \multicolumn{2}{|c|}{ Site $1^{2}$} & \multicolumn{2}{|c|}{ Site $2^{y}$} \\
\hline & Control & $\begin{array}{l}\text { Chiseled } \\
(0-60 \mathrm{~cm})\end{array}$ & Control & $\begin{array}{r}\text { Gypsum } \\
\text { (13 tha) }\end{array}$ \\
\hline \multicolumn{5}{|c|}{ Salinity of the saturation extract $\left(\mathrm{dS} \cdot \mathrm{m}^{-1}\right)$} \\
\hline $0-30$ & $3.5 a^{x}$ & $2.0 \mathrm{~b}$ & $2.6 \mathrm{a}$ & $3.5 b$ \\
\hline $30-60$ & $5.7 a$ & $4.9 \mathrm{~b}$ & $3.6 \mathrm{a}$ & $4.2 \mathrm{a}$ \\
\hline $60-90$ & $5.0 \mathrm{a}$ & $4.5 \mathrm{a}$ & $4.2 \mathrm{a}$ & $4.0 \mathrm{a}$ \\
\hline \multicolumn{5}{|c|}{ Sodicity of the saturation extract (SAR) } \\
\hline $0-30$ & 11.0 & $\cdots$ & $7.9 \mathrm{a}$ & $7.2 b$ \\
\hline $30-60$ & $\cdots$ & $\cdots$ & $9.1 \mathrm{a}$ & $8.6 b$ \\
\hline $60-90$ & -- & $\cdots$ & $10.2 \mathrm{a}$ & $10.1 \mathrm{a}$ \\
\hline
\end{tabular}

${ }^{2}$ Helmers and Miyamolo (1990)

"Unpublshed data, this laboratory.

Numbers followed by the same letter in rows are not significantly different at $P=0.05$. above also has been reported in many orchards irrigated with moderately saline water. in these cases, reduced water penetration has caused salt accumulation in the root zone, leading to loss of tree vigor and branch dieback (Miyamoto and Gobran, 1983). It may take 5 to 15 years for the salts to accumulate, depending primarily on salinity of irrigation water and soil permeability. The measures to deal with this problem have been chiseling or trenching followed by leaching irrigations as discussed earlier.

Chiseling is becoming a primary means of managing compaction-related problems in pecan orchards. The possible negative impact of chiseling through root damage seems to be rather insignificant as long as chiseling is performed along the strip between tree drip lines during the dormant period in alternate rows in one direction per season, Regrowth of roots from the point of cutting extends 50 to $100 \mathrm{~cm}$ in one season. There are some indications that systematic root pruning can be beneficial in terms of increasing rooting depths and root density, at least in young orchards. Regrowth of pecan roots is similar to compensatory growth from pruned tree branches, To obtain maximum root branching, the position of a chiseling knife should be moved away from tree trunks as the process is repeated. In high-density orchards, thinning usually begins at the age of 14 to 18 years. If chiseling is performed in alternate rows in one direction, it takes 4 years to return to the original position. Thus, three to four rounds of 4-yearcycle chiseling with decreasing widths can be applied before tree thinning; then a new round of chiseling can begin after tree thinning.

Once large tree roots begin to cover the entire orchard, chiseling is not the best option. Pecan roots are essential, not only for water and nutrient absorption but also for carbohydrate storage (Lockwood and Sparks, 1979). When crowded trees have high nut loading, root damage is likely to affect nut development and nut filling. An alternative to chiseling is the use of spikers, which make vertical holes or break up surface compaction with less damage to the tree roots. This type of equipment has not yet been used extensively, but some of the preliminary results show improved water infiltration. Additional testing is required to evaluate the performance of spikers in different soils

Another type of soil structural degradation is caused by high sodicity of irrigation water, which disperses soil particles under low salinity. In addition to the physical and chemical measures discussed in the previous section, vegetative covers may help reduce soil structural degradation, which takes place at the soil surface (Florenso et al., 1992; Glenn and Welker, 1989; Meek et al.,1992), and help develop deeper soil cracks, which are important in conducting water in clay soils. Decay of organic matter and $\mathrm{CO}_{2}$ release from plant roots also solubilize calcium from soil carbonate, thus reducing sodium accumulation (Robins, 1986). Field evaluation of the effects of vegetative covers on reducing sodium hazard in irrigated orchards is needed.

\section{Managing orchard floors}

Orchard soils must be conditioned to grow trees and facilitate equipment movement and nut harvesting. Trafficability is reduced in clay soils after irrigation or rain, and nut recovery in such soils can be poor when excessive cracks preformed. Some growers have managed trafficability and cracking problems through topdressing with a thin layer of sandy soils or sand, although the measure can be somewhat costly. Sand topdressing is likely to help water infiltration as well. If this option is used, sand topdressing may be made in two stages; first, over deep-chiseled clay, then over shallow-chiseled top soils at close spacings to reduce the abruptness of the boundary. When permeability of the clay layer is so low as to cause waterlogging, surface drainage measures or soil pitting or trenching through the clay layer maybe needed before topdressing,

When orchard floors consist of sand with loose gravel, excessive water infiltration, poor distribution and retention of water under surface irrigation, and, at limes, gravel pick-up by a harvester can be a problem, Some growers have corrected this problem by topdressing the sand with a thin layer of clay, followed by disking. Water distribution efficiency over the sand undersurface irrigation also can be improved through packing with a roller or using irrigation water loaded with suspended sediments. A thin layer of clay formed by the deposition of suspended sediments plugs some wafer-conductive pores in sand, thus reducing wafer infiltration (Miyamoto, 1989), If an extensive area of an orchard consists of sand, irrigation systems instead of soils should be modified for cost-effectiveness,

Many orchards have been converted to sodded floors. Sodding improves trafficability(in clay and sand) and provides habitats for beneficial insects; above all, sodded floors are cheaper to maintain than those under clean cultivation. However, there are many reports indicating adverse effects of sodding on growth and fruit yields of apples and peaches (Miller, 1983; Nielsen et al., 1984; Welker and Glenn, 1989). The effect of sodding on pecans appears to vary with sod type (Apel et al., 1979; Goff ef al., 1991) and possibly with cultivar (Kilby, 1979). Our experience with pistachios indicates that severe nitrogen competition will result during shoot and leaf growth, even under partial sodding (unpublished data). This is especially true when cool-season grasses and legumes are used for sodding. The peak growth of cool-season grasses and legumes overlaps with the shoot and leaf growth of many deciduous tree crops. Sodding after the peak shoot and leaf growth stage, especially in mature orchards, may have minimal effects on tree growth, as demonstrated in peaches (Loyne and Tan, 1988). At the same time, sodding at the later stage could affect nut development and filling. Sodding, for example, presents
Table 2. Tree responses and salinity of the soil-saturation extract before and after the rise of the water table within $40 \mathrm{~cm}$ of the soil surface at an orchard in EI Paso Valley near the Rio Grande.

\begin{tabular}{|lcccc|}
\hline & & \multicolumn{3}{c|}{ After (1986) } \\
\cline { 3 - 5 } Site & $\begin{array}{c}\text { Before (1984) } \\
\text { (all areas) }\end{array}$ & $\begin{array}{c}\text { Area } \\
1\end{array}$ & $\begin{array}{c}\text { Area } \\
2\end{array}$ & $\begin{array}{c}\text { Area } \\
3\end{array}$ \\
\hline $\begin{array}{l}\text { Tree rating } \\
\text { Soil salinity (dS. }{ }^{-1} \text { ) }\end{array}$ & Excellent & Fair & Dead & Dead \\
$0-30 \mathrm{~cm}$ & & & & 8.7 \\
$30-60 \mathrm{~cm}$ & 1.4 & 2.8 & 8.5 & 8.5 \\
$60-90 \mathrm{~cm}$ & 1.9 & 6.0 & 7.9 & 6.6 \\
\hline
\end{tabular}


competition for potassium uptake (Goff, 1991), which is important for shuck development. The effects of sodding during kernel development requires additional study. Sodding reduces, but does not eliminate, the need for alleviating soil compaction.

Mulching may bean attractive orchard-floor management option. However, this option is used rarely in pecans, as nuts are harvested with a sweeper. In young trees under sprinkler or drip irrigation, wood chips from tree pruning and thinning can be used for mulch, but in-depth studies are yet to be performed.

\section{Looking ahead}

One of the tasks in soil management involves refining chiseling and trenching operations, which have evolved largely through trial and error. This task requires improved understanding of root-pruning effects on tree performance and the rate of root regeneration, The use of various plows in young orchards with stratified soils and spiking the old root-bound orchard floor also require additional studies for different soil types, Likewise, the procedure for soil trenching in an orchard undergoing tree thinning is yet to be determined,

The positive and negative effects of soddedfloor management require careful examination, Since sodding affects many aspects of orchard maintenance activities, including soil structural maintenance, weed control, insect control, fertilization, irrigation, and nut harvesting, the decision to convert to sodded-floor management will have a significant effect on overall orchard management, Sodded-floor management also will affect quality of runoff and drainage water and can lead to environmentally sound orchard management. Sods absorb $\mathrm{NO}_{3}$, thus reducing $\mathrm{NO}_{3}$ leaching potential (e.g., Jackson et al., 1993), and they filter sediments that are the principal carriers of pesticides, However, the mechanism of reducing $\mathrm{NO}_{3}$ leaching is largely due to $\mathrm{NO}_{3}$ uptake by sods; thus, the competition factor must be resolved through additional research on sod management, Minimizing the use of herbicides and pesticides through conversion to sodded floors is also compatible with the objectives of reducing production costs and potential environmental hazards. The development of environmentally and economically sound soil and orchard-floor management, however, warrants additional research.

\section{Literature Cited}

Acharya, C.L. and I.P. Abro/. 1976 Effect of river sand on the permeability of a sodic soil. J. Indian Soc. Soil Sci. 24,245-252. Alben, A.O. 1958. Water logging of subsoil associated with scorching and defoliation of Stuart pecan trees. Proc Amer. Hort. Sci. 72:219-223.

Apel, G.W., M.W. Smith, and H.A. Hinrichs 1979. The effect of ground covers on tree performance and mechanical harvesting. Pecan South. p. 8-11.

Florunso,O.A., D.E. Ralston, T. Prichard and D.T. Louie, 1992 Cover crops lower soil surface strength, may improve soil permeability. Calif. Agr. 46:26-27.
Glenn, D.M. and W.V. Welker 1989. Orchard soil management systems influence rainfall infiltration. J Amer. Soc. Hort. Sci. 114:10-14.

Goff, W.D. 1991. Orchard floor management practices influence elemental concentrations in young pecan trees. HortScience 26:1379-1381.

Helmers, S. and S. Miyarnoto 1990. Mechanical and chemical practices for reducing salinity in pecan orchards. Proc. Natl. Irr. Conf. Amer. Soc. Agr. Eng. Publ. 04-90. p. 374-377.

Jackson, L.E., L.J. Wyland, J.A. Klein, R.F. Smith, and W.E. Chancy. 1993. Winter cover crops can decrease soil nitrate leaching potential. Calif. Agr. 47.12-15.

Kilby, M.W. 1979. Orchard floor management for young pecan trees $m$ the El Paso Valley. Pecan South (Jan.):26-27.

Lockwood, D.W. and D. Sparks. 1979 Pole of stored carbohydrates from tops and roots of pecan during the spring flush of growth. Pecan South 7:22-29.

Loyne, R.E.C. and C.S. Tan. 1988. Influence of cultivars, ground covers, and trickle irrigation on early growth, yield, and cold hardiness of peaches on Fox sand J. Amer. Soc. Hort. Sci. 1135:518-525.

Loustalot, A.J. 1945. influence of soil moisture conditions on apparent photosynthesis and transpiration of pecan leaves. J. Agr. Res. 71:519-532.

Meek, B.D. E.R. Rechel, L.M. Carter, W.R. DeTar, and A.L. Urie. 1992. Infiltration rate of a sandy loam soil: Effects of traffic, tillage and plant roots. Soil Sci. Soc. Amer. J. 56:908-913.

Miller, S.S. 1983. Response of young 'Topred Delicious' apple trees to orchard floor management and fertilization. J. Amer. Soc. Hort. Sci. 108:638-642.

Miyamoto, S. 1985. Water consumption. Growers need to know this to plan irrigation. Pecan South. p. 8-13.

Miyamoto, S. and S. Helmers. 1988. Selecting soils for irrigated pecan production. Pecan South 22:(2)8-12

Miyarnoto, S. and G. Gobran. 1983 Assessment and potential remedies of salinity problems in pecan orchards of the middle Rio Grande Basin Proc. Western Pecan Conf., Las Cruces, N.M. p. 1-

Miyamoto, S., G. Gobran, and K. Piela 1985. Salt effects on growth ion uptake of three pecan rootstock cultivars. Agron. J. 77:383388.

Miyamoto, S., T. Riley, G. Gobran, and J. Petticrew. 1986a. Effects of saline water irrigation on soil salinity pecan tree growth and nut production. Irr. Sci. 7:83-95

Miyamoto, S., G. Picchioni, and B. Storey. 1986b. Salinity: A major factor of poor tree performance in irrigated pecans, Pecan South (July-August):14-17.

Miyamoto, S. 1989. Reclamation of salt-affected pecan orchards. Proc. Texas Pecan Growers Assn. p.1-14.

Miyamoto, S. 1989. Causes and remedies of poor water infiltration in orchard soils Proc. Western Pecan Conf.

Miyamoto, S. and C. Enriquez. 1989. Comparative effects of chemical amendments for reclaiming moderately $\mathrm{Na}$-affected clayey soils. Irr. Sci 11:83-92.

Miyamoto, S, and J.L. Stroehlein. 1986. Sulfuric acid effects on water infiltration and chemical properties of alkali soils and water. Trans Amer. Soc. Agr. Eng. 29:1288-1296.

Neilsen, G.H., M. Meheriuk, and E.J. Hogue. 1984, The effect of orchard floor management and nitrogen fertilization on nutrient uptake and fruit quality of 'Golden Delicious' apple trees. HortScience 19:547-550.

Pandey, R.S. 1985. Effect of cracks on infiltration behavior in saltaffected soils. J. Indian Soc. Soil Sci. 33:137-140.

Rieger, M. and J.W. Daniell. 1988. Leaf water relations, soil-to-leaf resistance, and drought stress in pecan seedlings. J. Amer. Soc. HortSci. 113:789-793.

Robins, C.W. 1986. Sodic calcareous soil reclamation as affected by different amendments and crops. Agron. J. 78:916-920.

Smith, M.W.and P.L. Ager. 1988. Effects of soil flooding on leaf gas exchange of seedling pecan trees. HortScience 23:370-372. Smith, M.W. and R.D. Bourne. 1989. Seasonal effects of flooding on greenhouse-grown seedling pecan trees. HortScience 24:81-

Sparks, D. 1989. Drought stress induces fruit abortion in pecan HortScience 24:78-79.

Welker, W.V. and D.M. Glenn. 1989. Sod proximity influence the growth and yield of young peach trees J. Amer. Soc. Hort. Sci. 114:856-859.

Wildman, W.E., W.L. Pecock, A.M. Wildman, G.G. Goble, J.E. Pehrson, and N.V. O'Connel, 1988. Soluble calcium compounds may aid lowvolume water application. Calif. Agr. (Nov.-Dec.):7-8. 